\title{
Is Matthew 28:16-20 the summary of the Gospel?
}

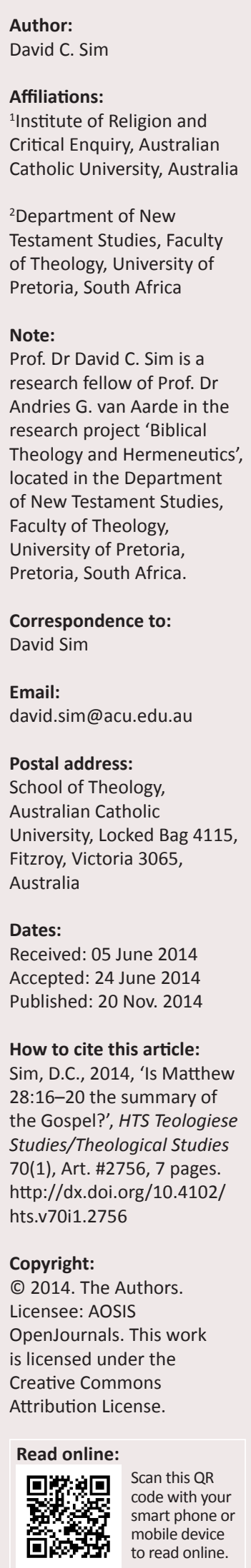

It is generally acknowledged that the Great Commission at the end of Matthew's Gospel is a dramatic and fitting end to the evangelist's narrative. In the eyes of many scholars this final pericope does more than simply conclude the Gospel; it serves as a summary of the text's major themes and even provides the interpretative key by which the earlier story should be read. This view, however, is questionable for two reasons. Firstly, the Great Commission introduces new themes and motifs into the Gospel story, which means that it cannot be viewed as a mere summary of what has come before. Secondly, this passage does not mention all the major themes of the Gospel. While some important motifs are included in the final pericope, there are others that receive no mention at all. This point too casts considerable doubt on the view that Matthew 28:16-20 serves to summarise Matthew's story of Jesus. Moreover, the Great Commission, despite recalling a number of earlier themes, looks more towards the time of the future Church than back to the time of 'the historical Jesus'. It is therefore better viewed as a bridging text that concludes one Christian story about the mission of Jesus and introduces another story about the history of the Church.

\section{Introduction}

One of the most powerful scenes in the Gospel of Matthew is the text's finale, which is usually described as the 'Great Commission'. In this pericope the risen Christ appears to his disciples on a mountain in Galilee, and announces to them that all authority in heaven and on earth has been given to him. Having proclaimed his transcendent majesty and power as the resurrected one, Jesus then commissions his disciples to embark on a new mission. He charges them to make disciples of all the nations, and instructs them to baptise new converts in the name of the Father, the Son and the Holy Spirit. He further orders them to teach and to obey all that he has commanded them, and he sends them on their mission with the words of comfort that he will be with them always until the end of the age. These five verses that conclude Matthew's Gospel form a fitting, powerful and memorable end to the Gospel, and it is no surprise that a massive amount of scholarly attention has been devoted to them (see Nolland 2005:1258-1259 for bibliography) and that scholars have focused on a wide variety of issues within this pericope.

As to its origin, while some scholars have argued that the Great Commission was completely created by Matthew (so Gundry 1994:593-597; Kingsbury 1974:573-579; Lange 1973:488-491), the majority of scholars contend that Matthew has heavily redacted traditional source material (so Davies \& Allison 1997:677-678; Hubbard 1974:101-136; Meier 1977b:407-416; Nolland 2005:1261; Schaberg 1982:313-335). In terms of its genre, the work of Hubbard (1974:1-136), which argues that Matthew based this text on Old Testament commissioning narratives, has won wide support (e.g. Allison 1993:263-265; Davies \& Allison 1997:679-680; Nolland 2005:1261), but others have maintained that the genre of the passage cannot be so easily categorised (Luz 2005:618-619; Meier 1977b:424). I have myself previously published on this fundamental passage positing an entirely new reading of the text, which suggests that the evangelist has constructed this pericope, at least in part, to serve his anti-Pauline agenda (Sim 2008a:377-392).

In this article, however, I do not wish to revisit the origin or genre of this material, nor do I intend to restate its anti-Pauline dimensions. Rather, I wish to explore another aspect of this fascinating text, which has occupied scholarly attention for decades. This is the widely held view that one of Matthew's primary purposes in the Great Commission, perhaps his major purpose, was to summarise the most important themes in his Gospel narrative. This has been expressed in a number of ways. Matthew 28:16-20 can be understood not simply as the climax of the Gospel but as a summary of the Gospel or as its hermeneutical key. As its interpretative key Matthew's story of Jesus must be read backwards as it were, with the earlier sections being understood in the light of its dramatic conclusion. It is this interpretation of the Great Commission that I wish to question in the current study. As important as this text is within the Gospel story, I will argue 
that it neither serves to summarise the preceding narrative nor does it provide the key that unlocks the meaning of Matthew's Gospel. Scholars have overstated their case in this respect. It will be maintained against this hypothesis that the Great Commission introduces new elements that cannot be viewed as summaries of what has gone before, and also that many important themes in the Gospel do not appear in the Gospel's conclusion, which calls into questions its status as a summary of the whole text. Further to this, I will suggest that Matthew 28:16-20 must be viewed as the Gospel's climax, but over and above this it needs to be appreciated that it looks more towards the future than back to the past. It is, in other words, a bridging passage that concludes Matthew's story of the 'historical Jesus' and points the reader to the new era of the universal mission of the Church which conducts its endeavours under the protection of the risen Christ.

\section{The Great Commission as the summary of the Gospel or as the key to its interpretation}

The emergence of the view that the Great Commission acts as a summary of Matthew's Gospel can be attributed to a short article by O. Michel, first published in German in 1950 (Michel 1950:16-26) and subsequently published in English translation in a collection of important Matthean studies edited by G.N. Stanton (Michel 1983:30-41). According to Michel (1983):

[T] he whole Gospel was written under this theological premise of Matt 28:18-20 (cf. 28:19 with 10:5ff; v. 20 with 1:23; also the return to baptism, cf. 3:1) ... the conclusion goes back to the start and teaches us to understand the whole Gospel, the story of Jesus, 'from behind'. Matt. 28:18-20 is the key to the understanding of the whole book. (p. 35, [original emphasis])

This short section of Michel's article has had an enormous impact on the field, and has garnered much support in the past 60 or so years. The following list of scholarly support and quotations is illustrative rather than exhaustive.

\section{In the view of P.F. Ellis (1974):}

In Matthew's gospel, the actions and the ideas (theology) progress steadily to the climactic missionary mandate of $\mathrm{Mt}$ $28: 18-20$, which provides not only a summary of the central themes of the gospel but a clue to its movement as well. (p. 24)

J.P. Meier states without any hint of disagreement that: 'The final pericope, unique to Matthew's Gospel, has been called the key to the understanding of the whole Gospel' (Meier 1980:367). O. Brooks comments that 'the concluding pericope (xxviii 16-20) has controlled the entire design of the Gospel of Matthew' (Brooks 1981:2). This view finds further support in the commentary of D.J. Harrington. Harrington notes that because Matthew 28:16-20 brings out the Gospel's main themes, '[i]t is possible to view Matt 28:16-20 as a summary of the whole Gospel' (Harrington 1991:416-417). A little later, D.A. Hagner affirms the earlier work of Michel and Ellis by stating that: 'These final five verses not only conclude the passion-resurrection narrative of chaps. 26-28, but also serve as the conclusion to the entire Gospel' (Hagner 1995:881).
In the view of C. Keener: 'In this closing pericope, Matthew recapitulates and develops the most important themes of his Gospel' (Keener 1999:715). Finally, we may cite the words of P. Foster (2004), who says in relation to Matthew 28:16-20:

These verses form the climax to the gospel, and in line with ancient rhetorical practice the main thrust of this literary work and its hortatory message are enshrined in its final charge. (p. 239)

These examples drawn from many decades testify to the continuing influence of Michel's $(1950,1983)$ work, but what is perhaps a little surprising is that most of these scholars do little more than refer to the work of Michel (or one his later supporters); it is a rare occurrence when scholars attempt to justify or supplement Michel's arguments.

The major exception to this rule is the majestic Matthean commentary by W.D. Davies and D.C. Allison (1997). These scholars begin their analysis of Matthew 28:16-20 with the statement that:

The grand denouement, so consonant with the spirit of the whole Gospel because so full of resonances with earlier passages, is, despite its terseness, almost a compendium of Matthean theology. (p. 687)

Not content with making a simple statement, these scholars make the effort to support it by providing detailed evidence. They produce no less than eleven pieces of evidence. These are (1) the motif of Galilee fulfils the prophecies in 26:32 and 28:7 and creates a bracket with 4:12. (2) The mountain setting recalls other mountain scenes in the Gospel, especially 4:8 and 5:1. (3) The reference to worshipping Jesus but some doubting refers back to 14:31-33. (4) Jesus being given all authority in heaven and on earth echoes 11:27 and also the prophecy of Daniel 7:13-14 that Jesus had previously applied to himself in 24:30;26:64. (5) The mention of making disciples is reminiscent of 13:52. (6) The reference to 'all the nations' overrides the earlier prohibition in 10:5-6 and realises the promise made to Abraham in Genesis 12; $18: 18$ and 22:18. (7) The baptismal formula of the Father, the Son and the Holy Spirit recalls the baptism of Jesus, where all three figures are mentioned. (8) The command to teach mentions a central theme and gives the disciples a task previously attached to Jesus alone. (9) In referring to 'all that I have commanded you', there is a general summary of all Jesus has taught and done in the Gospel. (10) The final 'I am with you always' forms an inclusio with 1:23 (cf. too 18:20). (11) The mention of the end of the age recalls 13:39, 40, 49; 24:3 and brings to mind Jesus' teaching about the end (Davies \& Allison 1997:687-688). It is the presence of all of these elements in the Gospel's finale that convince Davies and Allison that the Great Commission basically summarises the theological perspectives found in the Gospel.

Needless to say not all scholars share this view. It is interesting to note that the great German commentator, U. Luz, who has a similar list of correspondences between the Gospel's conclusion and the earlier sections of the Gospel (Luz 2005: 616), does not make the specific point that this pericope serves as a summary of the Gospel or is its interpretative key. Many other scholars too discuss Matthew 28:16-20 without 
any mention of Michel's point. It is also important to note that some exegetes make use of Michel's work in a more restrictive way. T.L. Donaldson views the final pericope as the key to understanding the mountain motif in the Gospel (Donaldson 1985:170-190), while a few more recent scholars understand the Great Commission as a summary not of the whole Gospel but only of Matthew's missionary theology (Evans 2012:482; Krentz 2004:24-31; Senior 2000:251-252). Still others have questioned Michel's view altogether. I will provide two recent and important examples. In his commentary on Matthew's Gospel, B. Witherington maintains that while the Great Commission reiterates some of the Gospel's major themes and draws together a number of threads in the text, it cannot really be called the key to the interpretation of Matthew (Witherington 2006:531). In similar vein, the commentary by R.T. France casts doubt over Michel's 'backwards' reading of the Gospel. France concedes that it is possible to read the texts theologically from the Great Commission to illuminate earlier parts of the Gospel, but he argues that both in literary terms and aesthetically it is preferable to read the story chronologically, from beginning to end, to appreciate fully unfolding revelation of the Son of God which reaches its climax in the final pericope (France 2007:1108-1109). In my view, both Witherington and France make valid points. Witherington is correct that the conclusion of the Gospel reiterates only some of the Gospel's major themes, while France is correct in his assertion that the Gospel should be read forwards rather than backwards, and that the Great Commission must be interpreted as the climax of the text and not as its summary or its interpretative key. In what follows I wish to flesh out more concretely the points raised by these scholars.

\section{New elements in the Great Commission}

If the Great Commission is truly a summary of the Gospel, then we should not expect to find the introduction of new elements into the narrative. But even a cursory reading of the text reveals that this is not the case. The Gospel's conclusion contains a number of new aspects that have not received prior mention in the text. In some ways the evidence compiled by Michel and Davies and Allison to demonstrate the parallels between the Great Commission and the earlier sections of the Gospel actually leads to the opposite conclusion. Let me provide two examples.

The triadic formula of baptism in the name of the Father, the Son and the Holy Spirit finds no mention at all in the previous parts of Matthew. In fact it appears nowhere in the New Testament (Schaberg 1982:9-16). While other early Christian texts know of baptism in the name of Jesus Christ (Ac 2:38; 10:48; Rm 6:3), Christ (G1 3:27) and the Lord Jesus (Ac 8:16; 19:5), Matthew's baptismal formula is unique in early Christian literature. Whether or not this formula reflects the baptismal practice of the Matthean community is an interesting issue, but one that cannot be pursued here. What is of relevance, are the evangelist's prior references to baptism in his narrative. Here we need to return to his account of John the Baptist at the beginning of his story. The preaching of the Baptist concerned repentance (Mt 3:2) and his baptism involved the confession of sins (Mt 3:6). We do not know in whose name, if any, John performed his baptism. While it is true, as Davies and Allison point out, that in the baptism of Jesus in Matthew 3:13-17 the Father, the Son and the Holy Spirit all feature, this hardly prepares the reader for the triadic baptismal formula in 28:19. The command to baptise in the name of the Father, the Son and the Holy Spirit is an entirely new feature introduced by the risen Christ that completely alters and transforms the baptismal practice of John the Baptist, creating in the process a very different rite of baptism that is relevant to the Christian Church in the post-resurrection period (Edwards 1985:94; Nolland 2005:1267-1268; Senior 1997:176).

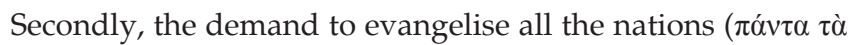
$\check{\varepsilon} \theta v \eta)$ is also new. Earlier in the narrative the Matthean Jesus makes clear that his own mission is to the lost sheep of the house of Israel (Mt 15:24) and he confines the mission of his disciples solely to the Jews by telling them to avoid the Gentiles and Samaritans (Mt 10:5-6). Even when Jesus meets Gentiles and praises their faith, as in the cases of the Centurion of Capernaum (Mt 8:5-13) and the Canaanite women (Mt 15:21-28), they seek him out and there is no indication that either becomes a follower of Jesus. Unlike Mark where there is arguably both a Jewish and Gentile mission during the ministry of Jesus, Matthew takes pains to confine the activity of Jesus to the Jews alone (Sim 2008b:156-159). At the end of the Gospel the prohibition against the Gentile mission is overturned by the risen Christ - even Davies and Allison concede this - and there is nothing in the narrative that prepares the reader for this surprising and unexpected turn of events (Evans 2012:484; La Grand 1995:239; Nolland 2005:1266). This is not a summary of what has happened previously in the narrative but is another completely new feature that the evangelist has introduced in this final scene.

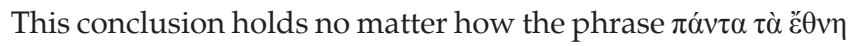
is understood. If it is translated as 'all the Gentiles', then two possibilities emerge. The text can be interpreted along the lines that the previous mission to Israel has now been revoked and is now replaced by the mission to the Gentiles (so Hare \& Harrington 1975:359-369; Harrington 1991:414-415). Any such replacement is hardly a summary of what has come before. Alternatively, A. von Dobbeler has argued that there is no replacement of the Jewish mission. On the contrary, the original Jewish mission continues and is now joined by a complementary but separate Gentile mission (Von Dobbeler 2000:31-32). Again the introduction of a second mission complementing the first is in no way a summary of earlier Gospel themes. Most scholars, however, accept the view

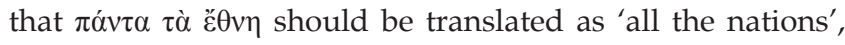
which includes both the Jews and the Gentiles (Davies \& Allison 1997:684; France 2007:1114-1115; Meier 1977a:94102; Nolland 2005:1265-1266). On this reading of the text, the original mission to the Jews is now expanded to include the Gentiles. Once more the expansion of the mission to the Jews 
to include the Gentile world cannot be viewed as a summary of earlier material. In short, no matter whether we view the missionary demand of the risen Christ as a replacement of an earlier mission, as a new but complementary mission or as an extension to the first mission, we are dealing with an entirely new feature in the narrative.

These two examples are sufficient for our purposes. By introducing new and even unexpected themes into his Gospel's conclusion, namely the triadic baptismal formula and the Gentile mission (however understood in relation to the original Jewish mission), it is clear that Matthew's purpose in this text involved much more than simply summarising some of the major themes in his Gospel.

\section{Dominant Matthean themes missing from the Great Commission}

Having established above that Matthew 28:16-20 can hardly be called a summary of the Gospel because it introduces new themes and does not simply recapitulate existing ones, I want now to turn to another point that equally calls that hypothesis into question. This is the issue raised by Witherington that the final scene of the Gospel does not include all of that text's major themes. It will be recalled from the summary of the position of Davies and Allison that they identified eleven significant Gospel themes that receive attention in the Great Commission. The discussion in the preceding section has cast considerable doubt on a couple of these, but even if for the sake of argument we accept the conclusions of these commentators on all eleven points, is it true that all the major themes in the Gospel receive attention in its climactic scene? Even a cursory glance at the text makes it immediately apparent that a number of dominant aspects of Matthew's narrative find no mention at all in the Great Commission. I will focus on three, although this number could be added to with little difficulty.

The first theme is the eschatological judgement and its aftermath. As I have argued in a detailed monograph, the Gospel of Matthew is dominated by an apocalypticeschatological perspective (Sim 1996). At the heart of the evangelist's apocalyptic-eschatological scheme lies the final and universal judgement, which Matthew describes in a number of passages 7:22-23; 19:28; 25:31-46) (Sim 1996:123127) and which he refers to constantly throughout his text using a variety of terms and metaphors - the judgement (12:41-42), the day of judgement (10:15; 11:22-24; 12; 36), the coming wrath $(3: 7)$, that day $(7: 22 ; 24: 36)$, the end of the age $(13: 39,40,49,50 ; 24: 3$; cf. 10:22; 24:6), and the harvest (3:12; 9:37-38; 13:36-43) (Sim 1996: 114-115). The evangelist is especially interested in the aftermath of the judgement, specifically the rewards of the righteous and the punishment of the wicked. With respect to the righteous, they will receive treasures in heaven $(6: 20 ; 19: 21$; cf. 13:44-46), inherit eternal life $(19: 16,29 ; 25: 46)$, participate in the eschatological banquet (8:11-12; cf. 22:1-14), and they will be like angels in heaven (22:30) and see God (5:8) (Sim 1996:140-145). As for the wicked, Matthew spells out in gruesome detail their particular fate. The ones who fail the test at the judgement will be sent to the outer darkness $(8: 12 ; 22: 13 ; 25: 30)$, they will weep and gnash their teeth $(8: 12 ; 13: 42,50 ; 22: 13 ; 24: 51$; 25:30), and they will be punished forever in the fires of Gehenna (cf. Mt 3:7-12; 5:22, 29-30; 7:19; 10:28; 18:8-9; 13:42, $50 ; 23: 15,33 ; 25: 46$ ) (Sim 1996:129-140). This emphasis on the judgement and especially the terrible fate of the wicked is one of the Gospel's major themes that permeate the teaching of Jesus throughout the narrative. As with other apocalypticeschatological authors, Matthew embraces and utilises this material because his community faced a number of crises (Sim 1996:181-221) and these themes are intended to provide the members of his community with an explanation of their current circumstances and to give them hope and encouragement that God will soon save and reward them and punish mercilessly their enemies (Sim 1996:222-242). In other words Matthew's heavy utilisation of apocalyptic eschatology is designed to meet the needs of his community in its time of great crisis, and its constant presence in the Gospel must be understood in that light.

Yet this theme, which is not merely an abstract theological idea but one of fundamental importance to the lives of Matthew's readers, receives no mention at all in the Great Commission. The suggestion of Davies and Allison that the reference to the 'end of the age' is meant to recall Jesus' teachings about the end events is grounded more in hope than reality. The emphasis in the closing statement that Jesus will be with the disciples until the end of the age falls more on the presence of Jesus during the time of the Church than on the eschatological events themselves. It does not immediately recall his teachings on the judgement or the horrible fate of the wicked. If the purpose of Matthew 28:1620 was to summarise the Gospel, then the evangelist has inexplicably omitted one of its most prominent features, and one which had immediate relevance to his community in its situation of crisis.

A second notable absence from the Great Commission is the conflict with Formative Judaism. It is well known that Matthew takes over from Mark and $Q$ the traditions in which Jesus comes into dispute with the scribes and Pharisees, and he redacts this material to intensify the extent of the conflict, and constructs other passages where the scribes and Pharisees are depicted in a very unfavourable light. In Matthew the scribes and Pharisees are described as hypocrites $(23: 13,15$, 23, 25, 27, 29; cf. 6:2, 5, 16; 15:7: 22:18; 23:3), blind men (23:16, $17,19,24,26)$, children of Gehenna (23:15) and a brood of vipers $(23: 23$; cf. $3: 7 ; 12: 34)$. They fail to practise what they preach (23:3), they place burdens on others (23:4), they love to be admired (23:5-7), they place their own tradition before the will of God (23:15-26), and are guilty of murder (23:29-36; cf. 22:6). These groups lead people astray (15:14), prevent them from entering the kingdom of heaven (23:13) and make them twice as much children of Gehenna as they are themselves (23:15). The Pharisees misinterpret the Torah (23:23) and Matthew describes a controversy between Jesus and these 
groups over Sabbath observance (12:1-14). In a further passage, the evangelist recounts a debate between Jesus and the Pharisees on the specifically Pharisaic practice of ritual hand washing prior to eating (15:1-20). Scholars have long debated the reason for Matthew's intense polemic against the scribes and Pharisees, and a consensus has emerged that the evangelist and his Christian Jewish community were engaged in a fierce dispute with Formative Judaism (Davies \& Allison 1997:692-704; Overman 1990; Repschinski 2000; Saldarini 1994; Sim 1998:109-163).

Formative Judaism is a term applied to the coalition of forces that grouped together after the disaster of the destruction of Jerusalem and its Temple in the year 70. This combined group was dominated by the scribes and Pharisees, and central to its programme was the correct observance of the Torah and obedience to the 'oral $\mathrm{Law}^{\prime}$ ', the so-called 'tradition of the fathers or elders'. The oral Law comprised rulings by Pharisaic sages concerning the application of the Mosaic Law as well as uniquely Pharisaic practices. The end of the Jewish war witnessed a power vacuum in Judaism, and Formative Judaism came into conflict with other Jewish groups which also had aspirations to rebuild the shattered Jewish faith in the period following the war (Overman 1990:35-71). Scholars agree that Matthew's small Christian Jewish community was involved in a prolonged and bitter dispute with local and much more powerful representatives of Formative Judaism, and this conflict explains the bitter polemic against the scribes and Pharisees that we find in this Gospel.

Given the prominence of this theme in the Gospel and its immediate relevance to the community for whom Matthew wrote, we should again expect a summary of the Gospel to include some mention of it. Yet, Matthew 28:16-20 makes no reference at all to this conflict nor does it provide any advice as to how the Christian Jewish Matthean community is to deal with this real and present danger in its local setting. It might be argued that the comforting promise of Jesus to be with his disciples or followers until the end of the age contains an oblique reference to the problems that they are currently enduring at the hands of the scribes and Pharisees, but even if this is so it still remains true that the Gospel's summary passage fails to mention, even obliquely, another dominant theme.

The third significant theme that also is absent from the Great Commission has been mentioned above in relation to the scribes and Pharisees. This is the issue of the Mosaic Law. While some exegetes downplay the importance of the Torah in Matthew's Gospel and community (Deines 2004, 2008:5384; Foster 2004:80-217), it is generally acknowledged that the Matthean Jesus expected his followers to observe the Torah and that as a result of this the evangelist's community was fully Law-observant (e.g. Cuvillier 2009:144-159; Konradt 2006:129-152; Overman 1990:73-90; Sim 1998:123-139; Snodgrass 1996:99-127). This is clearly delineated in the triad of passages in 5:17-19 where Jesus states that he has not come to abolish the Law and the prophets, that nothing at all, not even minor elements, can be taken away from the Law until the Parousia, and that his followers must observe all of the Torah, even its least commands, and teach them to others (Mt 5:17-19). Matthew also spells out Jesus' definitive messianic interpretation of the Torah, which emphasises love of God and neighbour, and which identifies justice, mercy and faith as the weightier matters of the Law (cf. 5:21-48; 7:12; 19:16$22 ; 22: 34-40 ; 23: 23$ ). As might be expected, it is the issue of the correct interpretation of the Torah that causes significant conflict between Jesus and the scribes and Pharisees in Matthew's story (cf. 12:1-14; 15:1-20; 22:34-40), and which no doubt was a source of real contention in the life of the Matthean community and its dispute with the leadership of Formative Judaism (Repschinski 2000). The Mosaic Law therefore is an extremely important component of Matthew's Gospel, which also had serious implications for Matthew's community in terms of its particular Christian praxis. As Jews who followed Jesus they observed the Torah in the manner prescribed by the Messiah, and it was this factor that largely contributed to the conflict with Formative Judaism. In the light of this observation, the absence of any mention of the Torah is decidedly awkward for those who see the Great Commission as a summary of the Gospel's major themes.

As a response to this point, one might argue that the Law is necessarily tied in with the demand of the risen Christ to observe all of his teachings. Within the context of the narrative, this would refer to all of Jesus' teachings earlier in the Gospel, and would of necessity include his teachings about the Torah. This argument is of course plausible, but again the connection is rather remote. A summary of the Gospel's major themes would still be expected to have some explicit reference to the Torah and its relationship to Jesus.

\section{Conclusions and further observations}

In conclusion let me make a few brief comments. I am in no way suggesting that the Great Commission is not an important pericope in the context of Matthew's Gospel. On the contrary, it is a powerful and dramatic conclusion or climax to the evangelist's story. It is here that we discover the cosmic significance of Jesus' resurrection. In his resurrected state, Jesus has been granted all authority (and power) in heaven and on earth. His first action in this new state is to send his disciples on a universal mission, with the demand to baptise converts according to the triadic baptismal formula and to teach them all that he has commanded, with the promise that he will be an abiding presence with them. It is a remarkable and memorable scene that is a fitting and even dramatic climax to the Gospel. But as important as this pericope is in the whole narrative, and as dramatic as it is in the context of Matthew's story, it is neither a summary of the Gospel nor does it provide the key to the text's interpretation. It does of course reintroduce or recall some important themes that appear earlier in the narrative - the inclusio with respect to 1:23 and 28:20, the mountain theme and so on - and Matthew no doubt expected his readers to pick up these references. But the Great Commission also introduces new elements, 
such as the reference to baptism in the name of the Father, Son and Holy Spirit, and the extension of the mission to all nations, and these motifs are not just new but unexpected.

On the other side of the coin, we find that other important themes in the text - the judgement and its aftermath, the dispute with Formative Judaism, and even the role of the Torah - find no place at all in the Gospel's conclusion. The omission of these central themes, all of which impact on Matthew's readers in their religious practice and their relations with other Jewish groups, presents a real difficulty if Matthew were using the Great Commission to summarise his Gospel message or to serve as its interpretative key. In regard to this point, it should be noted that Michel's work was published at a time when scholars did not sufficiently identify the relationship between the text and its intended readers. The introduction of sociological analysis in the 1990s and beyond has demonstrated that Matthew wrote his Gospel, not in a theological or historical vacuum, but in response to the needs and circumstances of his intended community or communities. It is therefore somewhat surprising to see that modern scholars from the 1990s onwards are still agreeing in large part with Michel's argument.

The lesson to be learnt from all of this discussion is that Matthew's Gospel is an extremely complex document which emphasises a wide range of theological and Christological points for a variety of reasons. He wished to reinforce to his intended readers certain doctrines to confirm their Christian Jewish convictions, but he also took considerable pains to address the particular circumstances that they were experiencing and enduring. In the light of these different motivations, it would simply be impossible for the evangelist to summarise all his important themes within a single pericope, and I do not think that was Matthew's intention in this passage. His intention, as I understand it, was quite different.

I agree entirely with the view of France and many other scholars that Matthew designed his Gospel to be read from beginning to end and that he constructed the Great Commission as the climax of his long narrative. But I would go even further than this. The Great Commission, as the name suggests, looks forward to the time of the Church much more than it looks back to the earlier parts of the Gospel. The allpowerful and all-authoritative risen Christ sends the disciples on a worldwide mission until the end of the age; that is the major point of this pericope. Whatever elements are recalled from earlier parts of the Gospel, the emphasis in this final passage is clearly on their future activity as missionaries in the period between the epiphany of Jesus on the mountain in Galilee as he commissions them and his arrival at the end of the age when he comes in judgement (La Grand 1995:240). It is precisely at this point that the Church which Jesus had earlier promised to build upon Peter (Mt 16:17-19) now comes into existence (Senior 2000:252). In the light of this Matthew 28:16-20 can be seen as Matthew's allusion to the history of the earliest Church, including its mandate by Jesus, its leaders, its universal mission, its initiation ritual and its emphasis on continuing to teach the words of Jesus who promises to protect them.

It is not an exaggeration to say, therefore, that Matthew's Great Commission is a much smaller version of the book of Acts that follows the Gospel of Luke. Unlike Luke, Matthew did not write a detailed history of the early Church, but he certainly points towards the future work of the Church in his carefully-crafted climax to his Gospel. And there is much in Matthew's final five verses that are also found, often in quite a different form and in much more detail, in Acts - the mandate to mission by Jesus, the universalism of the mission, the identity of those responsible for that mission, and the conditions of conversion. The Great Commission in Matthew thus serves as a bridge between two significant eras, the time of the historical Jesus and the period of the risen Christ and his Church. It concludes in dramatic fashion one story and it also stands as an introduction to another story which, for unknown reasons, the evangelist never records in detail. That second story concerns the work of the Christian church that in some ways continues the work initiated by the 'historical Jesus', but which in other ways involves new directives and directions by the risen Christ.

We may conclude that the common scholarly view that sees the Great Commission merely as a summary of the Gospel is wide off the mark in terms of Matthew's intentions. While it no doubt recalls earlier parts of the Gospel, its real purpose is, both conclusion and introduction, the end of one Christian story and a pointer to another.

\section{Acknowledgements Competing interests}

The author declares that he has no financial or personal relationship(s) that may have inappropriately influenced him in writing this article.

\section{References}

Allison, D.C., 1993, The new Moses: A Matthean typology, T \& T Clark, Edinburgh.

Brooks, O., 1981, 'Matthew XXVIII 16-20 and the design of the First Gospel', Journal for the Study of the New Testament 10, 2-28. http://dx.doi. org/10.1177/0142064X8100301001

Cuvillier, E., 2009, 'Torah observance and radicalization in the First Gospel, Matthew and first century Judaism: A contribution to the debate', New Testament Studies 55, 144-159. http://dx.doi.org/10.1017/S0028688509000101

Davies, W.D. \& Allison, D.C., 1997, A critical and Exegetical commentary on The Gospe according to Saint Matthew, vol. 3, T \& T Clark, Edinburgh. (The International Critical Commentary).

Deines, R., 2004, Der Gerechtigkeit der Tora im Reich des Messias: Mt 5, 13-20 als Schlüsseltext der matthäischen Theologie, Mohr Siebeck,Tübingen. (Wissenschaftliche Untersuchungen zum Neuen Testament, 177).

Deines, R., 2008, 'Not the Law but the Messiah: Law and righteousness in the Gospel of Matthew - An ongoing debate', in D.M. Gurtner \& J. Nolland (eds.), Built upon the Rock: Studies in the Gospel of Matthew, pp. 53-84, Eerdmans, Grand Rapids, MI.

Donaldson, T.L., 1985, Jesus on the Mountain: A study in Matthean theology, JSOT Press, Sheffield. (Journal for the New Testament Supplement Series, 8).

Edwards, R.A., 1985, Matthew's Story of Jesus, Fortress, Philadelphia, PA.

Ellis, P.F., 1974, Matthew: His mind and his message, Liturgical, Collegeville, PA.

Evans, C.A., 2012, Matthew, Cambridge University Press, Cambridge. (New Cambridge Biblical Commentary).

Foster, P., 2004, Community, law and mission in Matthew's Gospel, Mohr Siebeck, Tübingen. (Wissenschaftliche Untersuchungen zum Neuen Testament 2., Reihe 177).

France, R.T., 2007, The Gospel of Matthew, Eerdmans, Grand Rapids, MI. (The New International Commentary on the New Testament). 
Gundry, R.H., 1994, Matthew: A Commentary on his handbook for a mixed church under persecution, Eerdmans, Grand Rapids, MI.

Hagner, D.A., 1995, Matthew 14-28, Word Books, Dallas, TX. (Word Biblical Commentary, 33B).

Hare, D.R.A. \& Harrington, D.J., 1975, 'Make disciples of all the Gentiles (Mt 28:19)' Catholic Biblical Quarterly 37, 359-369.

Harrington, D.J., 1991, The Gospel of Matthew, Liturgical Press, Collegeville, PA. (Sacra Pagina 1)

Hubbard, B.J., 1974, The Matthean redaction of a primitive Apostolic commissioning: An Exegesis of Matthew 28:16-20, Scolars Press, Missoula, MT. (Society of Biblical Literature Dissertation Series, 19).

Keener, C.S., 1999, A Commentary on the Gospel of Matthew, Eerdmans, Grand Rapids, MI.

Kingsbury, J.D., 1974, 'The composition and Christology of Matt 28:16-20', Journal of Biblical Literature 93, 573-584. http://dx.doi.org/10.2307/3263833

Konradt, M., 2006, 'Die vollkommene Erfüllung der Tora und der Konflikt mit den Pharisäern im Matthäusevangelium', in D. Sänger \& M. Konradt (eds.), Das Gesetz im frühen Judentum und im Neuen Testament: Festschrift für Christoph Burchard zum 75. Geburtstag, pp. 129-152, Vandenhoeck \& Ruprecht, Göttingen.

Krentz, E., 2004, 'Missionary Matthew: Matthew 28:16-20 as summary of the Gospel', Currents in Theology and Mission 31, 24-31.

La Grand, J., 1995, The earliest Christian mission to 'All Nations' in the light of Matthew's Gospel, Eerdmans, Grand Rapids, MI.

Lange, J., 1973, Das Erscheinen des Auferstandenen im Evangelium nach Matthäus, Echter, Würzburg. (Forschung zur Bibel, 11).

Luz, U., 2005, Studies in Matthew, Eerdmans, Grand Rapids, MI.

Meier, J.P., 1977a, 'Nations or Gentiles in Matthew 28:19?', Catholic Biblical Quarterly 39, 94-102.

Meier, J.P., 1977b, 'Two disputed questions in Matt 28:16-20', Journal of Biblical Literature 96, 407-424. http://dx.doi.org/10.2307/3266193

Meier, J.P., 1980, Matthew, Veritas, Dublin. (New Testament Message, 3).

Michel, O., 1950, 'Der Abschluss des Matthäusevangeliums', Evangelische Theologie 10, 16-26. http://dx.doi.org/10.14315/evth-1950-1-603

Michel, O., 1983, 'The conclusion of Matthew's Gospel: A contribution to the history of the Easter Message', in G.N. Stanton (ed.), The interpretation of Matthew, pp. 30-41, Society for the Promotion of Christian Knowledge, London. (Issues in Religion and Theology, 3)
Nolland, J., 2005, The Gospel of Matthew, Eerdmans, Grand Rapids, MI. (The New International Greek Testament Commentary).

Overman, J.A., 1990, Matthew's Gospel and formative Judaism: The social world of the Matthean Community, Fortress, Minneapolis, MN.

Repschinski, B., 2000, The controversy stories in the Gospel of Matthew: Their redaction, form and relevance for the relationship between the Matthean community and formative Judaism, Vandenhoeck \& Ruprecht, Göttingen. (Forschungen zur Religion und Literatur des Alten und Neuen Testaments, 189).

Saldarini, A.J., 1994, Matthew's Christian-Jewish community, University of Chicago Press, Chicago, IL. (Chicago Studies in the History of Judaism).

Schaberg, J., 1982, The Father, the Son and the Holy Spirit: The Tridic phrase in Matthew 28:19b, Scholars, Chico, CA. (SBL Dissertation Series, 61).

Senior, D., 1997, The Gospel of Matthew, Abingdon, Nashville, TN.

Senior, D., [1983] 2000, 'The Mission Theology of Matthew', in D. Senior \& C. Stuhlmueller, The Biblical foundations for Mission, pp. 233-254, Orbis, Maryknoll, NY.

Sim, D.C., 1996, Apocalyptic Eschatology in the Gospel of Matthew, Cambridge University Press, Cambridge. (Society for New Testament Studies Monograph Series, 88)

Sim, D.C., 1998, The Gospel of Matthew and Christian Judaism: The history and social setting of the Matthean community, T \& T Clark, Edinburgh. (Studies of the New Testament and its World)

Sim, D.C., 2008a, 'Matthew, Paul and the origin and nature of the Gentile mission: The great commission in Matthew 28:16-20 as an Anti-Pauline tradition', HTS Teologiese Studies/Theological Studies 64, 377-392. http://dx.doi.org/10.4102/ hts.v64i1.28

Sim, D.C., 2008b, 'Matthew and Jesus of Nazareth', in D.C. Sim \& B. Repschinski (eds.), Matthew and his Christian contemporaries, pp. 155-172, T \& T Clark London. (Library of New Testament Studies 333).

Snodgrass, K., 1996, 'Matthew and the Law', in D.R. Bauer \& M.A. Powell (eds.), Treasures new and old: Contributions to Matthean studies, pp. 99-127, Scholars, Atlanta, GA. (SBL Symposium Series, 1).

Von Dobbeler, A., 2000, 'Die Restitution Israels und die Bekehrung der Heiden Das Verhältnis von Mt 10,5b.6 und Mt 28,18-20 unter dem Aspekt der Komplementarität. Erwägungen zum Standort des Matthäusevangeliums', Zeitschrift für die neutestamentliche Wissenschaft 91, 18-44.

Witherington, B., 2006, Matthew, Smyth \& Helwys, Macon, GA. (Smyth \& Helwys Bible Commentary). 